\title{
EXPRESSION OF SIR2, HDAC1 AND $A S H 2$ IN HONEY BEE (APIS MELLIFERA L.) QUEENS AND WORKERS
}

\author{
Cui Guan, Zhi Jiang Zeng*, Zi Long Wang, \\ Wei Yu Yan, Qi Zhong Pan \\ Honeybee Research Institute, Jiangxi Agricultural University, \\ Nanchang, Jiangxi, 330045, China \\ *corresponding author: bees1965@sina.com
}

Received 27 December 2012; accepted 23 March 2013

$\mathrm{S} \mathrm{u} \mathrm{m} \mathrm{m} \mathrm{a} \mathrm{r} \mathrm{y}$

The queen and worker bees have the same genetic makeup. However, the queen differs dramatically from the workers in anatomy, physiology, behavior, and lifespan. Three genes (sir2, ash2, and $h d a c 1$ ) have been shown to be associated with histone methylation and acetylation as well as longevity in worms and flies. The relative expression level of these genes was examined in the heads of queens and workers at different developmental stages. The sir2, ash2, and hdacl expression levels in newly emerged queens, egg-laying queens, and egg-laying workers were significantly higher than those in newly emerged workers, nurses, and foragers. We conclude that these genes are possibly "queen-like" genes.

Keywords: honeybee, castes, expression, genes.

\section{INTRODUCTION}

The honey bee (Apis mellifera L.) is an eusocial insect and the colony is normally composed of a single reproductive queen, tens of thousands of sterile workers, and hundreds of drones at mating season (Winston, 1987). Although the female castes (the queen and workers) are developed from the same fertilized eggs with identical genotype, the queen and workers exhibit striking differences in morphology, behavior, physiology, and life span (Winston, 1987; Hartfelder et al., 1993; Seehuus et al., 2006). Queen larvae feed on royal jelly throughout their larval development, while worker larvae are only fed royal jelly for their first 3 days (Winston, 1987). When a colony loses its queen, many workers will activate their own ovaries, resulting in changes in anatomy, physiology, and behavior. This would produce a subcaste close to the queen caste, which has an extended life span similar to "winter" bees (Dadant and sons, 1979).

Studies using worms and flies have revealed that longevity is controlled epigenetically by specific alterations in the chromatin state, including histone deacetylation, and histone methylation (Blander and Guarente, 2004; Beltran et al., 2007; Dang et al., 2009; Rogina et al., 2002; Rogina and Helfand2004; Greer et al., 2010; Siebold et al., 2010). An example of one of the histone methylation regulators is ash2. Two members of the histone deacetylation regulators are sir2 and hdac1. Studies demonstrate that ash 2 mutation, silencing or RNAi, extend life expectancy in Caenorhabditis elegans and Drosophila (Beltran et al., 2007; Greer et al., 2010; Siebold et al., 2010). Reduction of the hdacl expression increases mRNA levels of sir2, the direct over expression which extends the lifespan; while a decrease in sir2 level prevents the lifespan extension 
by hdacl (Rogina et al., 2002; Rogina and Helfand, 2004).

There is mounting evidence that queenbee phenotype is driven by epigenetic mechanisms through royal jelly. Kucharski et al. (2008) have revealed that nutrition can alter the epigenetic state of the genome and affect gene expression by modifying DNA methylation, resulting in caste differentiation. Furthermore, Spannhoff et al. (2011) have shown that royal jelly has histone deacetylase inhibitor (HDACi) activity, and has the ability to control epigenetic pathways. These data indicate that there are DNA methylation and histone acetylation pattern differences between queen and worker, due to their different feeding regimens. Genes related to histone acetylation and methylation are ash2, sir2 and hdacl. The relative mRNA abundance of ash2, sir2 and hdacl has not been studied in the honey bee. In this study, qRT-PCR was used to investigate the differential expression levels between the queen and worker honey bees.

\section{MATERIALS AND METHODS}

\section{Honey bee}

Honey bee (Apis mellifera ligustica) colonies were reared at the Honeybee Research Institute, Jiangxi Agricultural University, Nanchang, China $\left(28.46^{\circ} \mathrm{N}\right.$, $115.49^{\circ} \mathrm{E}$ ) using standard beekeeping techniques. For colony 1, one comb of sealed worker brood was incubated at $35^{\circ} \mathrm{C}$ and $40 \%$ relative humidity. Fifteen newly emerged workers (NW) were sampled. The remainder of the newly emerged workers were paint-marked, and transferred back to colony 1 and to a separate queenless colony (the queen was removed 10 days ago, and the queen cells were eliminated every day). Afterwards, we sampled fifteen, 10-12 day-old, young nurses (YN, identified as workers with their heads entering into the larval cells) and fifteen, 21-day-old regularly aged, "old" foragers (OF, identified as returning workers with pollen on their corbiculae) from colony 1. When the queenless colony appeared with multiple eggs in cells and drone brood only, fifteen marked, 21-day-old, egg-laying workers (LW, identified as marked workers backing into a cell with wings sticking out) were collected. At this age, the ovaries of the workers were $75 \%$ well-developed and they were pot-bellied (Koywiwattrakul and Sittipraneed, 2009). Using artificial grafting larvae from colony 1 to rear queens, the fifteen, newly emerged queens (NQ) were obtained after emerging from queen cells.

Fifteen 4-6 months old, egg-laying queens (LQ) were collected from 15 colonies of the Western honey bee, Apis mellifera, in the apiary of Shicheng county, Jiangxi province, China.

Each group (NW, YN, OF, LW, NQ, LQ) included 15 individuals: 3 heads of bees as a biological sample to minimize inter-individual variations and 5 biological replicates. All bees were snap-frozen in liquid $\mathrm{N}_{2}$ until processed.

With regard to colony 2 , we took similar samples.

RNA extraction and cDNA synthesis

Pools of 3 frozen heads were homogenized in liquid nitrogen using a mortar and pestle, and 50-100 $\mu \mathrm{g}$ of powdered tissue were used for extraction of total RNA with $1 \mathrm{~mL}$ of Trizol Reagent (Invitrogen) according to the manufacturer's instructions. The RNA concentration of each RNA sample was measured in triplicate using a spectrophotometer (GeneQuant, Pharmacia). The purity of the total RNA was determined as the $260 \mathrm{~nm} / 280 \mathrm{~nm}$ ratio with expected values between 1.8 and 2.0. RNA integrity was determined by agarose gel $(1.5 \%)$ electrophoresis, and ethidium bromide staining. The amount of total RNA was standardized to $1 \mu \mathrm{g}$. Synthesis of cDNA was performed using Invitrogen SuperScript III first-strand protocol. During first-strand cDNA synthesis, the RNA/primer mixture consisting of $1 \mu \mathrm{g}$ of RNA, $3 \mu \mathrm{L}$ oligo $(\mathrm{dT})_{20}(50 \mu \mathrm{M})$, and DEPC-treated water to a final volume of $20 \mu \mathrm{L}$ was incubated at $70^{\circ} \mathrm{C}$ for $5 \mathrm{~min}$, and instantly placed on ice for at least $1 \mathrm{~min}$. The cDNA synthesis mixture consisted of $10 \mu \mathrm{L}$ RT buffer $(5 \times), 8 \mu \mathrm{L}$ dNTP mix (10 mM), $1 \mu \mathrm{L}$ RNase OUTTM $(40 \mathrm{U} / \mu \mathrm{L})$, 
9.5 $\mu \mathrm{L}$ DEPC-treated water, and $1.5 \mu \mathrm{L}$ SuperScript III RT $(200 \mathrm{U} / \mu \mathrm{L})$. The cDNA synthesis mixture $(30 \mu \mathrm{L})$ was added to the RNA/primer mixture. The reaction was incubated at $42^{\circ} \mathrm{C}$ for $60 \mathrm{~min}$, and $75^{\circ} \mathrm{C}$ for $5 \mathrm{~min}$. The products were kept at $-80^{\circ} \mathrm{C}$ for later reactions.

\section{Primer design and real-time PCR assays}

The resulting cDNA templates were used for quantitative measurement by real-time quantitative PCR (Bio-Rad IQ2, USA) for the expression levels of the three specific genes, with $\beta$-actin as an appropriate internal control (Lourenço et al., 2008). Primers were designed based on mRNA sequence using Primer 5.0 software with the expected $63^{\circ} \mathrm{C}$ annealing temperature. Primer sequences and genes are summarized in Table 1.

The reaction system includes: $10 \mu \mathrm{L}$ IQ SYBR Green Supermix (Bio-Rad, USA), $0.5 \mu \mathrm{L}(10 \mu \mathrm{M} / \mathrm{L})$ forward primer, $0.5 \mu \mathrm{L}$ $(10 \mu \mathrm{M} / \mathrm{L})$ reverse primer (Invitrogen), $7 \mu \mathrm{L}$ sterile water and $2 \mu \mathrm{L}$ cDNA template. The cycling parameters were: preliminary $94^{\circ} \mathrm{C}$ for $2 \mathrm{~min}, 40$ cycles including $94^{\circ} \mathrm{C}$ for $15 \mathrm{sec}, 63^{\circ} \mathrm{C}$ for $30 \mathrm{sec}$, and $72^{\circ} \mathrm{C}$ for $30 \mathrm{sec}$. The specificity of the PCR products was verified by melting curve analysis, for each sample. The reference and target genes for each sample, were run in the same plate to eliminate interplate variations.

\section{Data analysis}

The $C_{T}$ value for each biological replicate was obtained by calculating the arithmetic mean of three technical replicate values. Standard curves were prepared using five points with progressive quantities and samples in each plate to calculate the PCR efficiency (E) value for each gene (the concentration of the cDNA is within the first to the fifth point).

The relative gene expressions were calculated using Liu and Saint's (2002) formula:

$$
\mathrm{R}_{0, \mathrm{~T}} / \mathrm{R}_{0, \mathrm{R}}=\frac{\left(1+\mathrm{E}_{\mathrm{R}}\right)^{\mathrm{C}_{\mathrm{r}, \mathrm{R}}}}{\left(1+\mathrm{E}_{\mathrm{T}}\right)^{\mathrm{C}_{\mathrm{r}, \mathrm{r}}}}
$$

$R_{0, T}$ : initial reporter fluorescence for target gene,

$R_{0, R}$ : initial reporter fluorescence for the reference gene,

$R_{0, T} / R_{0, R}:$ normalization for target gene relative expression levels,

$E_{\mathrm{R}}$ : reference gene amplification efficiency,

$\mathrm{E}_{\mathrm{T}}$ : target gene amplification efficiency,

$C_{T, R}^{\mathrm{T}}: C_{T}$ value of reference gene,

$C_{T, T}^{T, R}: C_{T}$ value of target gene.

Relative expression levels were square root transformed to reach the normality. The differential expressions were analyzed by analysis of variance (ANOVA) using StatView (v 5.01, USA).

Description of primer sequences and genes used for qRT-PCR assays

\begin{tabular}{|c|c|c|c|}
\hline Gene & Primer sequence $\left(5^{\prime} \rightarrow 3^{\prime}\right)$ & Acc. Number & Amplicon size (bp) \\
\hline$\beta$-actin & $\begin{array}{c}\text { Forward } \\
\text { TCCTGGAATCGCAGATAGAATG } \\
\text { Reverse } \\
\text { GGAAGGTGGACAAAGAAGCAAG }\end{array}$ & AB023025 & 140 \\
\hline sir2 & $\begin{array}{c}\text { Forward } \\
\text { TGGCGAAGGACTTCCGGATGC } \\
\text { Reverse } \\
\text { TGCTACTGGCCGGACCTTCA }\end{array}$ & XM_395386 & 106 \\
\hline ash2 & $\begin{array}{c}\text { Forward } \\
\text { TCGTGGTCGCAATGCAAAACGT } \\
\text { Reverse } \\
\text { GGTGCATGTGGATCAGGTTCAGC }\end{array}$ & XM_397014 & 180 \\
\hline hdac1 & $\begin{array}{c}\text { Forward } \\
\text { GGTTCTGTAGCTGCTGCGGTGA } \\
\text { Reverse } \\
\text { GGCATGATGTAAACCACCACCCC }\end{array}$ & XM_394976 & 81 \\
\hline
\end{tabular}




\section{RESULTS}

Results from Fig. 1 indicate that when compared to adult sterile workers (NW, $\mathrm{YN}$ and $\mathrm{OF}$ ), the relative expression levels of ash2, sir2 and hdacl in queens (NQ and LQ) and egg-laying workers (LW) showed starkly higher levels $(\mathrm{P}<0.05$, ANOVA). There were no significant differences among NW, YN, and $\mathrm{OF} \quad(\mathrm{P}>0.05$, ANOVA). longevity gene (sir2)) in Caenorhabditis elegans and Drosophila. Results in the honey bee were not entirely consistent, however, with those in Caenorhabditis elegans and Drosophila. Although many gene expression regulating pathways are conservative among species, species specificity still exists, i.e. juvenile hormone affected the expression of vitellogenin and lifespan in opposite directions between Drosophila and Apis mellifera

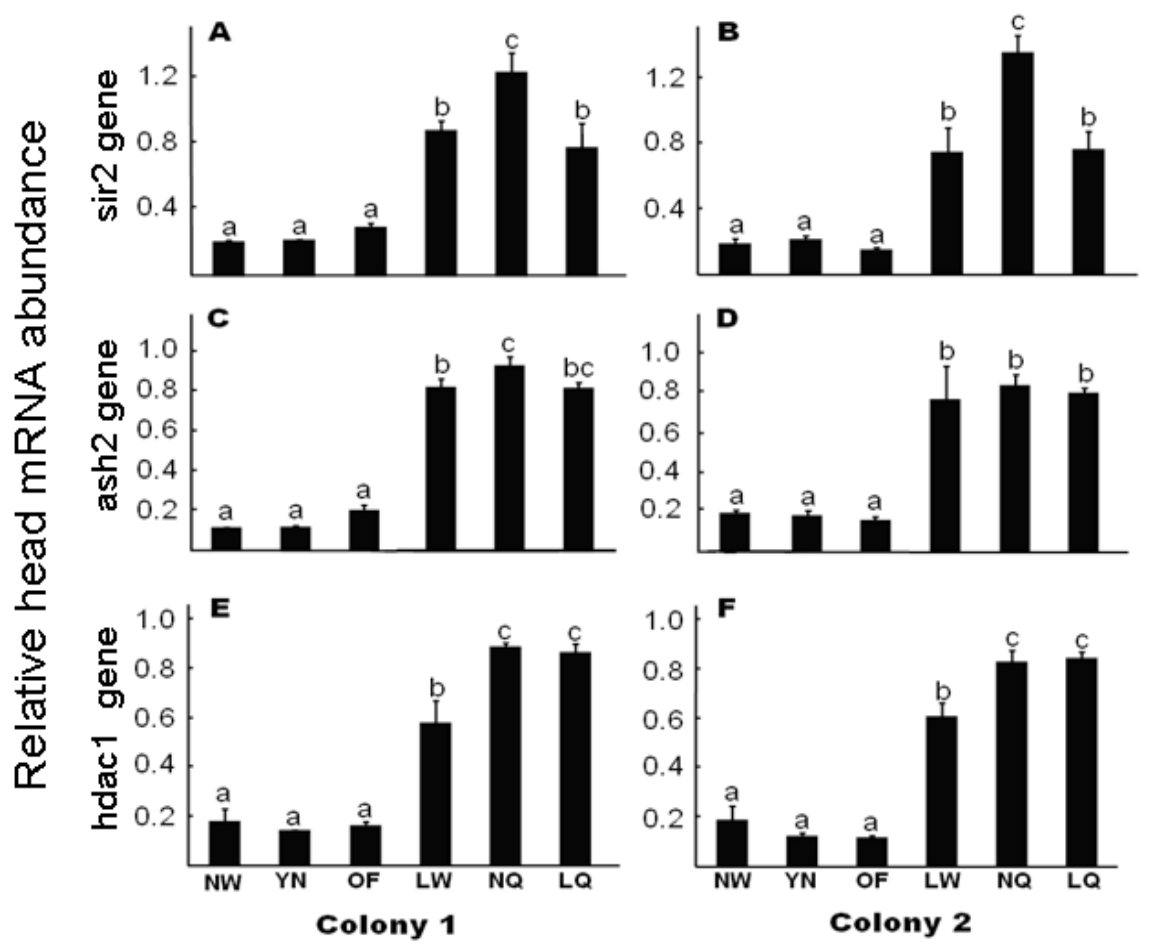

Fig. 1. Relative expression levels of sir2, ash2, hdac1 in female honey bee heads.

NW: newly emerged workers; YN: 10-12 days old, young nurses; OF: 21-day-old, regularly aged, "old" foragers; LW: 21-day-old, egg-laying workers; NQ: newly emerged queens; LQ: 4-6 month old, egg-laying queens. Different letters on top of the bars indicate significant difference $(\mathrm{P}<0.05)$ with Fisher's Protected Least Significant Difference. Each bar corresponds to a single group represented as the mean \pm S.E. of its biological replicates.

\section{DISCUSSION}

Our results indicate that ash2, sir2, and hdacl could be regarded as candidate loci for queen-like morphology. These candidate genes are lifespan related genes (two ageing genes (ash 2 and $h d a c 1$ ) and one
(Corona et al., 2007). Moreover, some specific single genes, like vitellogenin, even affected multiple physiological processes (Nelson et al., 2007). Thus, ash2, sir2 and hdacl in the honey bee are not necessarily involved in the exact same pathways as in fruit fly. 
In the case of egg-laying workers, when the emergency absence of the queen occurs, some egg-laying workers can emit a pheromone which mimics the queen's scent, and inhibits other workers from laying eggs. Some egg-laying workers are even attended by a retinue of workers which feed and lick her like a queen (Winston, 1987). Schäfer et al. (2006) revealed that royal jelly as a protein source was necessary for oogenesis. This meant that egg-laying workers were dominantly fed trophallactically to attain reproductive status in queenless colonies. The egglaying workers have a prolonged life span similar to diutinus bees ("winter" bees) (Dadant and sons, 1979; Münch et al., 2008). Egg-laying workers have much in common with queen castes in physiology, such as, reproductive activity and longevity. In addition, studies demonstrated that the relative mRNAs abundance of vitellogenin in virgin queens, egg-laying queens, and egg-laying workers was significantly higher than that in sterile workers (Grozinger et al., 2007; Guidugli-Lazzarini et al., 2008). Also, Grozinger et al. (2007) detected 221 "queen-like" genes associated with reproductive physiology in reproductive workers. In our study, the expression levels of ash2, sir2 and hdac1 in egglaying workers (LW) were significantly higher than those in sterile workers (NW, $\mathrm{YN}$, and OF). The same trend was with queens. Thus, we speculate, that these genes are "queen-like" genes, and may be involved with a "queen-like" physiology. This includes characteristics such as longevity and ovaries activation.

A number of gene activities have been found to be involved in caste determination. Barchuk et al. (2007) reported 240 differentially expressed genes between developing queens and workers. In addition, Lyko et al. (2010) found over 550 genes significantly differentially methylated between queens and workers as well as a few of differentially methylated genes belonging to the histone gene family. Similarly, Foret et al. (2012) sequenced the larval methylomes in both queens and workers and found the important role of DNA methylation in shaping alternative phenotypes in honey bees. Thus, there are a plenty of candidate loci for caste determination in female honey bees, and sir2, hdacl and ash 2 are only three more candidates - equal to, though probably not better than, other loci indicated in those previous publications. Moreover, the exact function of ash2, sir2, and hdacl will need to be studied in future research, through more experiments such as genetic manipulations or RNA interference.

\section{CONCLUSIONS}

Ash2, sir2 and hdacl may be "queenlike" genes, and may be involved in "queen-like" morphology.

\section{ACKNOWLEGEMENTS}

We thank XB Wu, ZX Zeng, F Zhang, and WX Wang for their help in conducting experiments. We are also grateful to Mr. I. Drobac, Mr. W. Austin and Mr. J. Pierre for revising this manuscript. This work was supported by the Earmarked Fund for the China Agriculture Research System (No. CARS-45-KXJ12) and the National Natural Science Foundation of China (No. 31060327).

\section{REFERENCES}

Barchuk A. R., Cristino A. S., Kucharski R., Costa L. F., Simões Z. L., Maleszka R. (2007) Molecular determinants of caste differentiation in the highly eusocial honeybee Apis mellifera. BMC Dev Biol., 7: 70.

Beltran S., Angulo M., Pignatelli M., Serras F., Corominas M. (2007) Functional dissection of the ash2 and ash1 transcriptomes provides insights into the transcriptional basis of wing phenotypes and reveals conserved protein interactions. Genome Biol., 8(4): R67.

Blander G., Guarente L. (2004) - The Sir2 family of protein deacetylases. Annu. Rev. Biochem., 73: 417-435. 
Corona M., Velarde R. A., Remolina S., Moran-Lauter A., Wang Y., Hughes K. A., Robinson G. E. (2007) - Vitellogenin, juvenile hormone, insulin signaling, and queen honey bee longevity. Proc. Natl. Acad. Sci. U.S.A., 104(17): 7128-7133.

Dadant and sons (1979) - The hive and the honey bee, Dadant, Hamilton, pp. 50.

Dang W., Steffen K. K., Perry R., Dorsey J. A., Johnson F. B., Shilatifard A., Kaeberlein M., Kennedy B. K., Berger S. L. (2009) Histone H4 lysine 16 acetylation regulates cellular lifespan. Nature, 459(7248): 802-807.

Foret S., Kucharski R., Pellegrini M., Feng S., Jacobsen S. E., Robinson G.E., Maleszka R. (2012) DNA methylation dynamics, metabolic fluxes, gene splicing, and alternative phenotypes in honey bees. Proc. Nat. Acad. Sci. U. S. A., 109(13): 4968-4973.

Greer E. L., Maures T. J., Hauswirth A. G., Green E. M., Leeman D. S., Maro G. S., Han S., Banko M. R., Gozani O., Brunet A. (2010) - Members of the H3K4 trimethylation complex regulate lifespan in a germlinedependent manner in C. elegans. Nature, 466(7304): 383-387.

Grozinger C. M., Fan Y., Hoover S. E. R., Winston M. L. (2007) - Genome wide analysis reveals differences in brain gene expression patterns associated with caste and reproductive status in honey bees (Apis mellifera). Mol. Ecol., 16(22): 48374848 .

Guidugli-Lazzarini

K. R., do Nascimento A. M., Tanaka E. D., Piulachs M. D., Hartfelder K., Bitondi M. G., Simões Z. L. (2008) Expression analysis of putative vitellogenin and lipophorin receptors in honey bee (Apis mellifera L.) queens and workers. J. Insect Physiol., 54(7): 1138-1147.

Hartfelder K., Tozetto S. O., Rachinsky A. (1993) - Sex-specific developmental profiles of juvenile hormone synthesis in honey bee larvae. Roux's Arch. Dev. Biol., 202(3): 176-180.
Koywiwattrakul P., Sittipraneed S. (2009) - Expression of Vitellogenin and Transferrin in Activated Ovaries of Worker Honey Bees. Apis mellifera, Biochem. Genet., 47(1-2): 19-26.

Kucharski R., Maleszka J., Foret S., Maleszka R.(2008) - Nutritional control of reproductive status in honeybees via DNA methylation. Science, 319(5871): 1827-1830.

Liu W., Saint D. A. (2002) - A new quantitative method of real time reverse transcription polymerase chain reaction assay based on simulation of polymerase chain reaction kinetics. Anal. Biochem., 302(1): $52-59$

Lourenço A. P., Mackert A., Cristino A.S., Simões Z. L. P. (2008) - Validation of reference genes for gene expression studies in the honey bee, Apis mellifera, by quantitative real-time RT-PCR. Apidologie, 39(3): 372-385.

Lyko F., Foret S., Kucharski R., Wolf S., Falckenhayn C., Maleszka R. (2010) - The honey bee epigenomes: differential methylation of brain DNA in queens and workers. PLoS Biol., 8(11): e1000506.

Münch D., Amdam G., Wolschin F. (2008) - Ageing in a eusocial insect: molecular and physiological characteristics of life span plasticity in the honey bee. Funct. Ecol., 22(3): 407-421.

Nelson C. M., Ihle K. E., Fondrk M. K., Page R. E., Amdam G. V. (2007) - The gene vitellogenin has multiple coordinating effects on social organization. PLoS Biol., 5(3): e62.

Rogina B, Helfand S. L. (2004) - Sir2 mediates longevity in the fly through a pathway related to calorie restriction. Proc. Nat. Acad. Sci. U. S. A., 101(45): 15998-6003.

Rogina B, Helfand S. L., Frankel S. (2002) - Longevity regulation by Drosophila Rpd3 deacetylase and caloric restriction. Science, 298(5599): 1745. 
Schäfer M., Dietemann V., Spannhoff A., Kim Y. K., Noel J., Pirk C. W. W., Neumann P., Crewe R., Raynal M., Gharibyan V., Su M. B., Hepburn H., Tautz J., Crailsheim K. Zhou Y. Y., Li J., Castellano S., (2006) - Individual versus social pathway Sbardella G. (2011) - Histone deacetylase to honeybee worker reproduction (Apis mellifera): pollen or jelly as protein source for oogenesis? J. Comp. Physiol. A. Neuroethol. Sens. Neural. Behav. Physiol., 192(7): 761-768.

Seehuus S. C., Norberg K., Gimsa U., Krekling T., Amdam G. V. (2006) Reproductive protein protects sterile honey bee workers from oxidative stress. Proc. Natl. Acad. Sci. U.S.A., 103(4): 962-967.

Siebold A.P., Banerjee R., Tie F., Kiss D. L., Moskowitz J., Harte P. J. (2010) - Polycomb Repressive Complex 2 and Trithorax modulate Drosophila longevity and stress resistance. Proc. Nat. Acad. Sci. U. S. A., 107(1): 169-174.

\title{
EKSPRESJA GENÓW SIR2, HDAC1 AND ASH2 U MATEK I ROBOTNIC PSZCZOLY MIODNEJ (APIS MELLIFERA L.)
}

\author{
Guan C., Zeng Z. J., Wang Z. L., \\ Yan W. Y., Pan Q. Z. \\ S t r e s z c z e n i e
}

Matki pszczele i robotnice wyposażone są w ten sam garnitur genetyczny. Jednak matki różnią się znacznie od robotnic pod względem anatomicznym, fizjologicznym, behawioralnym, jak również pod względem długości życia. U nicieni i muszek wykazano związek trzech genów (sir2, ash2, and hdac1) z metylacją i acetylacją histonów oraz z długością życia osobników. W niniejszych badaniach określono względny poziom ekspresji tych genów w głowach świeżo wygryzionych robotnic, młodych pszczół karmicielek, „starych” pszczół zbieraczek, robotnic składających jaja, świeżo wygryzionych matek oraz matek czerwiących. Względny poziom ekspresji badany był za pomocą techniki PCR opartej o barwnik SYBR Green. Poziom ekspresji genów sir2, ash2 i hdacl u świeżo wygryzionych matek, matek czerwiących oraz robotnic składających jaja był istotnie wyższy niż u świeżo wygryzionych robotnic, pszczół karmicielek i zbieraczek ( $<<0.05$, ANOVA). Pomiędzy świeżo wygryzionymi robotnicami, karmicielkami i zbieraczkami nie stwierdzono istotnych różnic ( $\mathrm{P}>0.05$, ANOVA). Stąd geny te mogą być odpowiedzialne za różnicowanie się cech fenotypowych charakterystycznych dla matek i robotnic.

Słowa kluczowe: pszczoła miodna, kasty, ekspresja, geny. 